\author{
Associate Professor Silvo DAJČMAN, PhD \\ E-mail: silvo.dajcman@um.si \\ Department of Economic Policy \\ University of Maribor, Faculty of Economics and Business
}

\title{
NONLINEAR EFFECTS OF MONETARY POLICY ON THE CONSUMER LOANS MARKET
}

\begin{abstract}
This paper contributes to the literature on nonlinear effects of monetary policy on different economic variables. We apply threshold vector autoregression analysis to study nonlinear transmission of euro area monetary policy shocks to the supply and demand in the euro area's consumer credit market. Two regimes of financial stress and two of gross domestic product (GDP) growth are modeled and then separately studied the effects of shocks in the shadow rate of monetary policy in the euro area. We find that the effects of monetary policy are larger in the high financial stress and low GDP growth regimes than in their counterparts (low financial stress and normal GDP growth, respectively). The response of demand for loans is generally larger than that of supply of loans. No nonlinearities associated with the size of the monetary policy shock are found.
\end{abstract} nonlinearity.

Keywords: monetary policy, business and financial cycles, loans,

\section{JEL Classification: C32, E51, E32, G01}

\section{Introduction}

The recent financial and economic crises weighed negatively on credit activity in the euro area, and in response the monetary policy authority aimed not only to stimulate economic activity and raise inflation expectations, but also to revive credit activity $(\mathrm{ECB}, 2015)$. A proper monetary policy response to the challenge requires answering a question (see e.g. ECB, 2011, ECB, 2015): Does transmission of monetary policy in crises differ compared to "normal" times? The present study analyzes differences in the transmission of European Central Bank (ECB) monetary policy to the euro area consumer loans market ${ }^{1}$ in these states of the world, which requires nonlinear analysis. ${ }^{1}$ This segment of the household loans market, in which households primarily borrow to finance the
purchases of durable goods, is smaller than the housing loans market, reaching approximately $1 / 4$ of
the total volume of the euro area's bank loans to households (ECB, 2017), and in the literature has
attracted considerably less attention than the housing (mortgage) loans market. Brady (2008) argues
that monetary policy measures that enhance accessibility of consumer credit make consumption

DOI: 10.24818/18423264/54.2.20.14 
A possibly nonlinear interaction between monetary policy and credit activity has attracted only limited attention in the literature. One strand of that literature (Chang \& Jansen, 2005; Gambacorta\& Rossi, 2007) investigates asymmetric responses of bank loans to positive and negative monetary policy shocks. The second strand of literature (Avdjiev\&Zeng, 2014; Tenreyro\&Thwaites, 2016; Aikman et al., 2017), more related to our research, is interested in the nonlinear response of credit to monetary policy shocks during different states of the business and credit cycles, respectively.

We divert from the literature in two main respects. First, unlike the existing literature, which is interested in the total credit activity, we focus on the consumer credit market. Moreover, we discern the supply from the demand for loans. Second, Avdjiev and Zeng (2014) and Tenreyro and Thwaites (2016) study the nonlinear relationship between monetary policy and credit, conditioning on the state of the business cycle, while Aikman et al. (2017) condition on the credit cycle (credit-togross domestic product (GDP) gap). In contrast, we study the effects of monetary policy on the consumer loans market during (i) low and normal economic growth of the euro area and (ii) low and high financial stress. Because these cycles may not overlap perfectly, such an analysis yields a more comprehensive understanding of the transmission mechanism.

This paper also aims to explore whether larger monetary policy shocks result in disproportionally larger effects. To answer all the questions, the threshold vector autoregression (TVAR) modeling framework and the nonlinear impulse response analysis are applied.

\section{Literature review}

The theoretical literature contrasts two opposing views on the efficiency of monetary policy in influencing economic and credit activity during different stages of business and financial stress cycles. The first view claims that monetary policy is more efficient in spurring credit and economic activity during recessionary or low economic growth and financial stress phases than in the counterpart states of the economy (i.e., during normal economic growth and low financial stress, respectively). Several different strands of literature corroborate that consumer credit activity during economic and financial turndowns may weaken due to (i) elevated information asymmetry, triggered for instance by increased financial, macroeconomic, or (economic) policy uncertainty, negatively affecting the availability of loans (Baum et al., 2013; Bonciani\& van Roye, 2016) or credit demand (e.g. due to the detrimental effect on household consumption) (Miao, 2004), (ii) the inverse relationship between the procyclical net worth of consumer

smoothing more likely, which is important from macroeconomic perspective. Knowledge of the effects of monetary policy on the consumer market through different states of the economy may therefore be important for the conduct of monetary policy. 
borrowers (net worth, acting like collateral in bank loan agreements)and anticyclical availability of loans, as explained in the financial accelerator literature (Bernanke \& Gertler, 1989; Bernanke et al., 1999), and (iii) the sensitivity of availability (supply) of bank loans to the bank's balance sheet health, which may worsen abruptly during economic and financial downturns due to overleverage, exposure to asset price volatility, or interbank interdependencies (Brunnermeier\&Sanikov, 2011; Mittnik\&Semmler, 2013). These mechanisms act as magnifiers of initial shocks and deepen economic and/or financial stress. Expansionary monetary policy in this environment can alleviate credit constraints and spur credit activity (and in turn economic activity) more than in an environment of lower credit constraints (Bernanke et al., 1999; Dalhaus, 2017) only if it also manages to moderate different types of uncertainties in the economy (Bekaert et al., 2013; Jannsen et al., 2015). The second view hypothesizes the opposite: Monetary policy actions are less efficient in a crisis than in the normal states of the economic or financial cycle. This may result as a consequence of the central bank not being able to offset the adverse impact of uncertainty because of zero lower bound constraints (Bonciani\& van Roye, 2016; Basu\&Bundick, 2017), sticky bank interest rates (Bonciani\& van Roye, 2016)or deleveraging and balance sheet repair due to excessive risk-taking and debt accumulated during the normal state of the economy (Borio, 2014).

Following diverging theoretical predictions, the effectiveness of monetary policy during different states of the economy is an empirical question. Empirical studies that examine a possibly nonlinear interaction between monetary policy and credit include Chang and Jansen (2005), Gambacorta and Rossi (2007), Avdjiev and Zeng (2014), Tenreyro and Thwaites (2016), and Aikman et al. (2017). Chang and Jansen (2005) and Gambacorta and Rossi (2007) investigate nonlinearities in the responses of bank loans to positive and negative monetary policy shocks, respectively, while Avdjiev and Zeng (2014), Tenreyro and Thwaites (2016), and Aikman et al. (2017) study nonlinearities in the response during different states of the business and credit cycle, respectively. Chang and Jansen (2005), studying the US, find that the growth of bank loans (total balance sheet volume of commercial banks) declines sharply following a contractionary impulse of the Federal Reserves. There are no differences in the magnitude of responses between expansionary and tightening monetary policy shocks as long as the policy rate shock is not larger than 1.5 standard deviations. Larger contractionary shocks lead to a more pronounced response than larger expansionary shocks. Gambacorta and Rossi (2007), who study nonlinearity between monetary policy and the aggregate bank lending in euro area over the period 1985-2005, also establish that a contractionary monetary policy affects aggregate credit activity more than expansionary policy.Avdjiev and Zeng (2014) study the regime-dependent effectiveness of monetary policy in the US. They identify three regimes of economic growth (subpar, moderate, and high GDP growth regimes) and find than the effect of monetary policy shocks on credit growth (total volume of credit to

DOI: 10.24818/18423264/54.2.20.14 


\section{SilvoDajčman}

businesses and households) is largest in the high GDP growth regime. The responses of credit spreads to a monetary policy shock are similar across the regimes. Tenreyro and Thwaites (2016) analyze for the US the response of the private nonfinancial credit-to-GDP ratio to monetary policy impulse and document a stronger response in economic expansions than in downturns. Aikman et al. (2017) separate between low and high credit gap regimes and find that in the former regime, when the credit-to-GDP ratio less its estimated long-run trend is below zero, the response of the credit-to-GDP gap is larger than during the latter regime.

\section{Methodology}

The nonlinear nature of monetary policy with respect to output growth and financial stress is captured by a TVAR model with two regimes (see Alessandri\&Mumtaz, 2017; Mumtaz et al., 2018):

$Y_{t}=\left[a_{1}+\sum_{i=1}^{P} C_{1, i} Y_{t-i}+\sum_{1}^{1 / 2} e_{t}\right] R_{t}+\left[a_{2}+\sum_{i=1}^{P} C_{2, i} Y_{t-i}+\sum_{2}^{1 / 2} e_{t}\right]\left(1-R_{t}\right),(1)$

where monthly euro area variables are contained is vector $Y_{t}$ in the following order: the growth of real GDP $\left(y_{t}\right)$, inflation $\left(p_{t}\right)$, financial stability indicator $\left(f_{t}\right)$, shadow rate for monetary policy stance in the euro area $\left(i_{t}\right)$, credit standards $\left(s_{t}\right)$, and credit demand $\left(d_{t}\right) . a_{1}$ and $a_{2}$ are regime-specific vectors of a constant, $C_{1, i}$ and $C_{2, i}$ are regime-specific matrices of TVAR coefficients, $P$ is the number of lags ${ }^{2}, \Sigma_{1}$ and $\Sigma_{2}$ are regime-specific covariance matrices, $e_{t} \sim N(0,1)$ is a vector of error terms, and $R_{t}$ is a variable governing regime-switch. $R_{t}$ can take two values:

$R_{t}=1$ if $w_{j, t-d} \leq w_{j}^{*}$,

$R_{t}=0$ if $w_{j, t-d}>w_{j}^{*}$,

where $w_{j, t-d}$ is the threshold variable, $j=f_{t}, y_{t}$, and $w_{j}^{*}$ is the threshold level determined endogenously by model (1). Being interested in the nonlinear nature of monetary policy with respect to business and financial stress cycles, the threshold variable is sequentially the $d$-month delay of $y_{t}$ and $f_{t}$, respectively. Conditioned on the threshold variables, the euro area at each observed time is in one of the following regimes: (i) low GDP growth $\left(R_{t}=1\right)$ or normal GDP growth regime $\left(R_{t}=0\right)$ or (ii) low financial stress $\left(R_{t}=1\right)$ or high financial stress regime $\left(R_{t}=\right.$ $0)$.

Estimation of (1) is Bayesian, following closely the methodology of Alessandri and Mumtaz (2017): A natural conjugate prior is applied for estimation of parameter estimates, and the Gibbs sampler of Chen and Lee (1995), with

${ }^{2}$ Following, e.g., Afonso et al. (2011), $P$ is determined by information criteria of a linear model. Note that (1) nests a linear model. 
20,000 iterations and discarding the first 15,000 iterations, is applied to approximate the posterior distribution. Maximum delay $(d)$ is set at 3 . For a detailed description and setting, refer to Alessandri and Mumtaz (2017).

To infer the dynamic nonlinear effects of monetary policy on the consumer loans market, a nonlinear impulse response of a particular consumer loan market variable is computed (see Koop et al., 1996) by simulation (500 replications are used) as a difference between two conditional expectations of the variable, the first one given the regime-specific history and size (and the sign of a) structural shock (in monetary policy) and the second one the regime-specific history without the shock. Monetary policy shocks are identified by assuming a recursive structure, as found in the literature. More specifically, the slow-moving variables $\left(y_{t}\right.$ and $\left.p_{t}\right)$ are followed by $f_{t}$, and $c_{t}$, and the monetary policy variable $i_{t}{ }^{3}$, while the consumer loans market variables $\left(s_{t}\right.$ and $\left.d_{t}\right)$ are ordered last. ${ }^{4}$ All computations are made in Matlab, applying the code of Alessandri and Mumtaz (2017).

\section{Data and empirical results}

Model (1) is estimated on monthly euro area data for September 2004 December 2018. The starting date is limited by the data for the ECB's shadow rate. The description of the data series is contained in Table 1.

Table 1. Definition of variables

\begin{tabular}{|c|c|c|}
\hline Variable & Definition & Source \\
\hline$y_{t}$ & $\begin{array}{l}\text { The annual percentage change (log-differenced) of real GDP, } \\
\text { monthly frequency; the quarterly working day, and seasonally } \\
\text { adjusted real GDP series was disaggregated to monthly series } \\
\text { applying the method of Chow-Lin }(1971){ }^{5} \text { using the monthly } \\
\text { industrial production series as an indicator series. }\end{array}$ & $\begin{array}{c}\text { Eurostat } \\
\text { (https://ec.europa.eu/eur } \\
\text { ostat/data/database; } \\
\text { series: GDP series } \\
\text { [namq_10_gdp] and } \\
\text { industrial production } \\
\text { series [sts_inpr_m]) } \\
\end{array}$ \\
\hline$p_{t}$ & $\begin{array}{l}\text { Inflation, computed as an annual percentage change (log-differenced) } \\
\text { of seasonally and working-day adjusted harmonized index of } \\
\text { consumer prices (HICP), monthly frequency. }\end{array}$ & $\begin{array}{l}\text { ECB Statistical Data } \\
\text { Warehouse } \\
\text { (https://sdw.ecb.europa.e } \\
\text { u; series HICP } \\
\text { [ICP.M.U2.Y.000000.3.I } \\
\text { NX]) }\end{array}$ \\
\hline$f_{t}$ & $\begin{array}{l}\text { Indicator of financial stress. We opt to use the Composite Indicator } \\
\text { of Systemic Stress (CISS) for the euro area, as for instance Holló et } \\
\text { al. (2012) and Kremer (2016). The indicator represents the realized } \\
\text { systemic stress in the euro area. For a detailed description, refer to } \\
\text { Holló et al. (2012). Monthly series are obtained from weekly as an } \\
\text { average. }\end{array}$ & $\begin{array}{c}\text { ECB Statistical Data } \\
\text { Warehouse } \\
\text { (https://sdw.ecb.europa.e } \\
\text { u; series: CISS - } \\
\text { Composite Indicator of } \\
\text { Systemic Stress } \\
\text { [CISS.D.U2.Z0Z.4F.EC. } \\
\text { SS_CI.IDX]) }\end{array}$ \\
\hline
\end{tabular}

${ }^{3} \mathrm{~A}$ similar ordering of the first five variables can be found in the monetary policy VARs; see, e.g., Kremer (2016).

${ }^{4}$ Followinglinear VAR models of monetary policy transmission channel that include credit market variables (e.g.,Lown\& Morgan, 2006).

${ }^{5}$ For this, the Matlab code of Quilis (2019) was applied.

DOI: 10.24818/18423264/54.2.20.14 
SilvoDajčman

\begin{tabular}{|c|c|c|}
\hline$i_{t}$ & $\begin{array}{l}\text { Shadow rate for the ECB, computed by Wu and Xia (2016), known } \\
\text { to represent well the stance of monetary policy in the euro area also } \\
\text { after } 2009 \text {, when the policy rates hit the zero bound. Monthly } \\
\text { frequency. }\end{array}$ & $\begin{array}{l}\text { Jing Cynthia Wu page } \\
\text { (https://sites.google.com/ } \\
\text { view/jingcynthiawu/shad } \\
\text { ow-rates) }\end{array}$ \\
\hline$s_{t}$ & $\begin{array}{l}\text { An indicator of changes in the availability of consumer loans. } \\
\text { Following recent research on monetary policy transmission (Lown\& } \\
\text { Morgan, 2006), bank lending survey answers can be used to proxy } \\
\text { for availability (or supply) and demand for loans. The time series } s_{t} \\
\text { measures changes in the euro area's availability of consumer loans } \\
\text { and is based on the ECB Bank Lending Survey responses to the } \\
\text { question related to changes in the credit standards for consumer loans } \\
\text { in the past quarter. The value of the variable is computed as a balance } \\
\text { between the percentage of positive (increase in credit standards) and } \\
\text { percentage of negative answers (lowering of credit standards). A } \\
\text { positive (negative) balance thus indicates that the credit standards } \\
\text { have increased (dropped), implying that the availability of loans has } \\
\text { dropped (increased). The survey is conducted quarterly, and the } \\
\text { monthly series is estimated from original time series of the ECB by } \\
\text { the temporal disaggregation method of Chow-Lin (1971), using the } \\
\text { Matlab code of Quilis (2019). }\end{array}$ & $\begin{array}{c}\text { ECB Statistical Data } \\
\text { Warehouse } \\
\text { (https://sdw.ecb.europa.e } \\
\text { u; series: Bank Lending } \\
\text { Survey,[BLS.Q.U2.ALL. } \\
\text { Z.H.C.B3.ST.S.BWFNE } \\
\text { T]) }\end{array}$ \\
\hline$d_{t}$ & $\begin{array}{l}\text { An indicator of changes in the demand for consumer loans, proxied } \\
\text { by the ECB Bank Lending Survey responses to the question relating } \\
\text { to the changes in demand in consumer loans in the past quarter. As } \\
\text { for the variable } s_{t} \text {, the value of the variable is a balance between a } \\
\text { percentage of positive answers (increase in credit demand) and a } \\
\text { percentage of negative answers (reduction in credit demand). A } \\
\text { positive (negative) balance thus indicates that the demand for } \\
\text { consumer loans has increased (dropped). The monthly series is } \\
\text { estimated from the original quarterly data by the temporal } \\
\text { disaggregation method of Chow-Lin (1971), using the Matlab code } \\
\text { of Quilis (2019). }\end{array}$ & $\begin{array}{c}\text { ECB Statistical Data } \\
\text { Warehouse } \\
\text { (https://sdw.ecb.europa.e } \\
\text { u; series:Bank Lending } \\
\text { Survey, } \\
\text { [BLS.Q.U2.ALL.Z.H.C. } \\
\text { B3.ZZ.D.BWFNET]) }\end{array}$ \\
\hline
\end{tabular}

The first plot in Figure 1 shows the high financial stress and low GDP growth regime periods in the euro area, as endogenously determined by model (1). The threshold value, as determined by (1), for the financial stress threshold variable is $w_{f_{t}}^{*}=0.2177$ and for the GDP growth threshold variable $w_{y_{t}}^{*}=1.0388$. The euro area economy is thus characterized as being in a financial stress regime if $w_{f_{t}, t-d} \leq 0.2177$ and in a low GDP growth regime if $w_{y, t-d} \leq 1.0388$. Three periods of high financial stress (the first coincides with the global financial crisis and the first wave of the euro area crisis, the second with the second wave of the euro area crisis, and the third with a shorter spell of financial stress associated with the British vote to leave EU) and low growth periods (the first associated with the Great Recession and the second with the euro area crisis) were identified. The plot conveys simultaneous high financial stress and low GDP growth regimes in the period from mid-2009 until 2011, and then from the third quarter of 2011 until the last quarter of 2012. The business and financial stress cycles, however, do not overlap perfectly: The first identified high financial stress period started before and stretched beyond the identified low-growth regime period. The second identified high financial stress period started before but also finished earlier than the lowgrowth phase of the euro area business cycle. 
Nonlinear Effects of Monetary Policy on the Consumer Loans Market

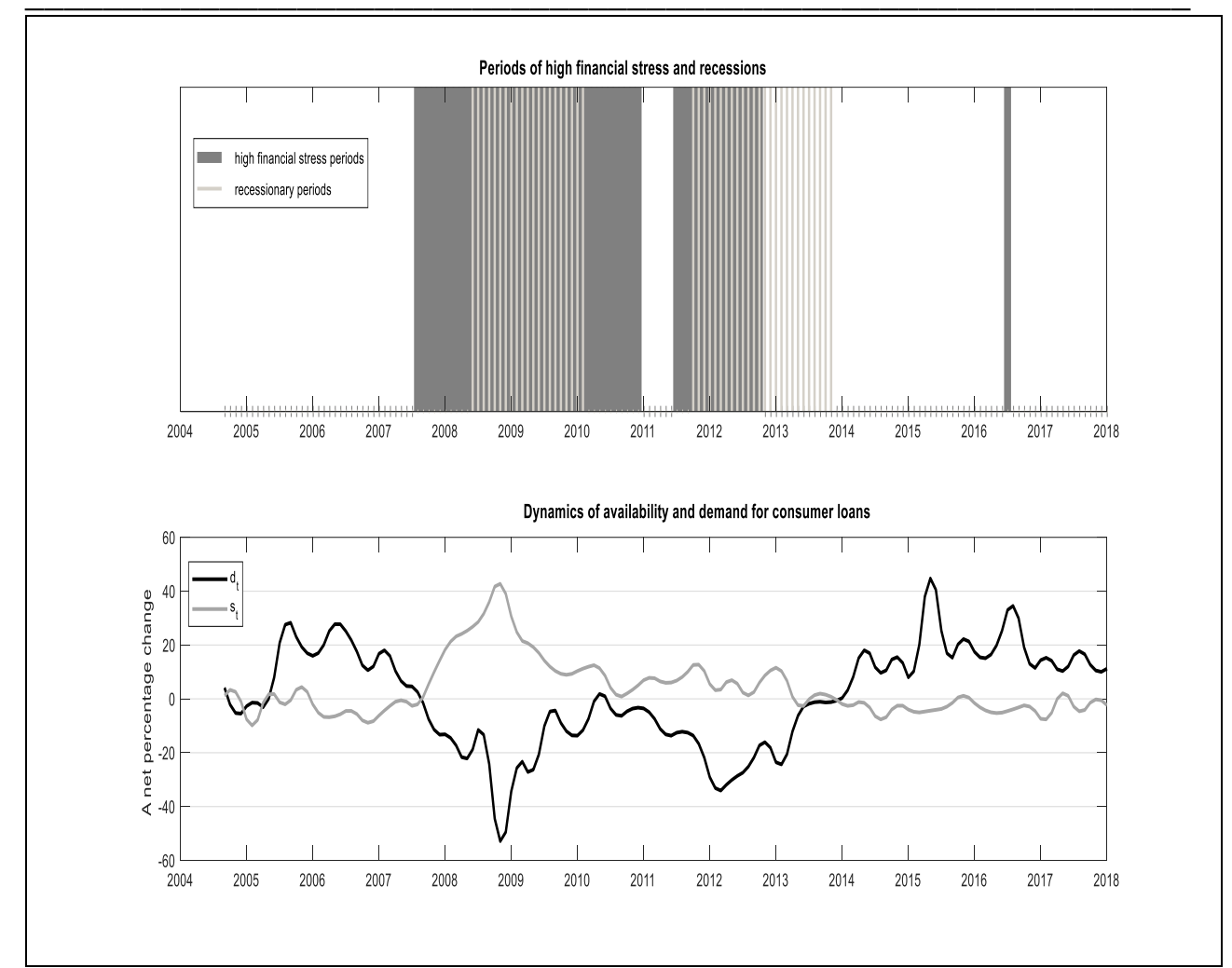

Note: The first plot shows bars of periods defined as high financial stress (dark grey bars) and low GDP growth (light grey sterns). The second plot shows the dynamics of variables $s_{t}$ and $d_{t}$.

Figure 1. High financial stress and low GDP growth regimes in the euro area as determined by the TVAR model and the dynamics of credit standards (availability of loans) and demand for consumer loans

The second plot in Figure 1 shows that the credit standards for consumer loans significantly increased (thus availability of loans dropped) in 2008-2010, coinciding largely with the identified high financial stress and low GDP growth in this period, while demand for consumer loans in the same period contracted. Evidently, worsening economic conditions and financial stress in the observed period were mirrored in the consumer loans market.

The results of nonlinear impulse response analysis are presented next. Figure 2 shows the responses of credit standards and demand for loans to a 1 standard deviation (STD) expansionary monetary policy shock (i.e., a reduction in the shadow rate) during a high and normal financial stress regime (the first panel) and during low and normal GDP growth regimes (the second panel).

DOI: 10.24818/18423264/54.2.20.14 


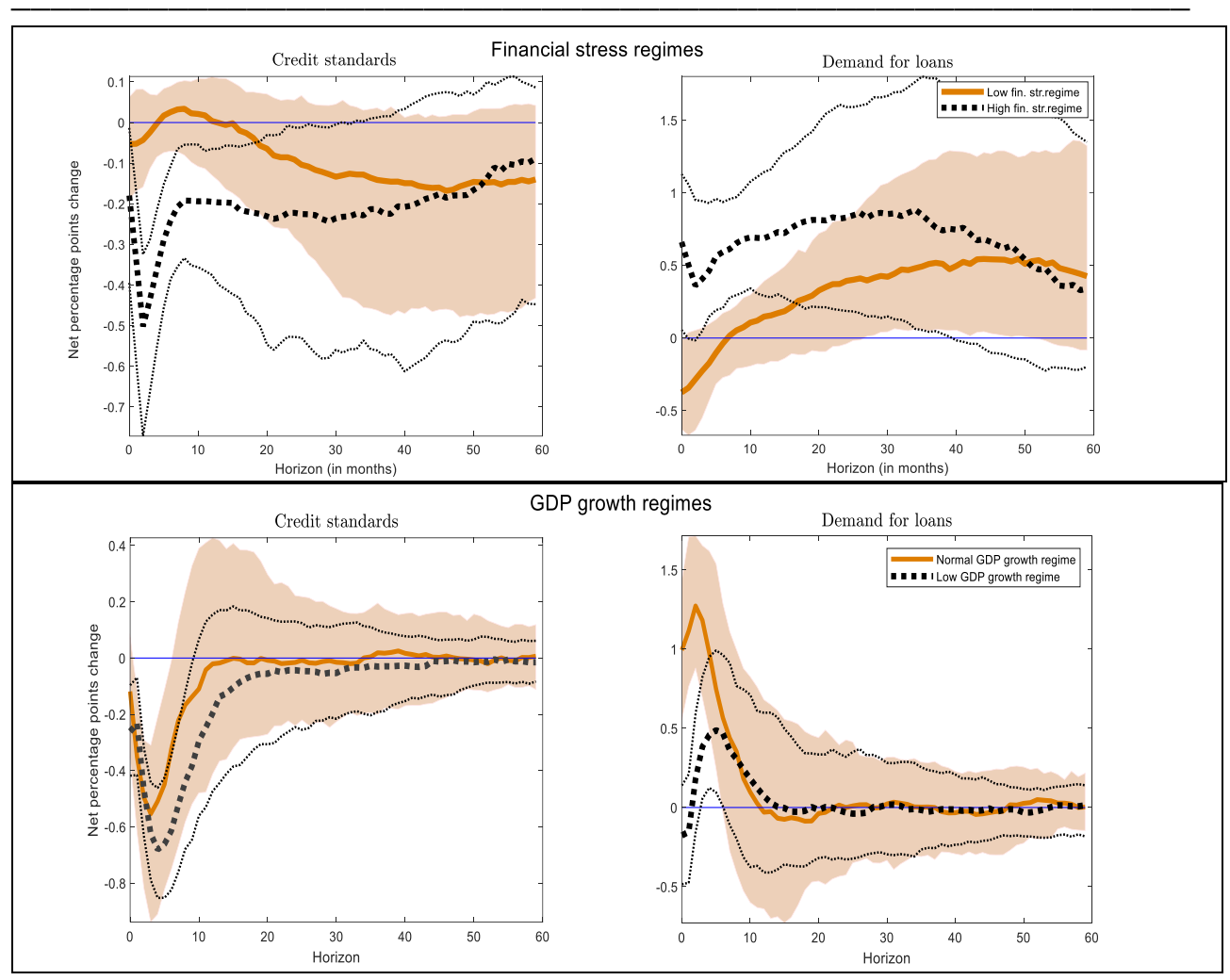

Notes: Drawn are the nonlinear median impulse responses of consumer loans market variables to a one std. dev. decrease in the ECB shadow rate $\left(i_{t}\right)$ over the horizon of 5 years and the 68 percent error bands. The responses to a shock in the two different regimes of variable $f_{t}$ and variable $y_{t}$ are compared.

Figure 2. Nonlinear impulse responses of credit standards $\left(s_{t}\right)$ and demand for loans $\left(d_{t}\right)$ to a 1 standard deviation expansionary monetary policy shock

Figure 2 shows that shocks in the monetary policy affect credit standards (availability of loans) as well as demand for consumer loans. When the euro area is in high financial stress, the effect of expansionary policy is larger than when the euro area is in a regime of low financial stress (first panel of Figure 1). When in high financial stress, the improved financial conditions provoked by expansionary monetary policy instantly reduce the credit standards banks apply (thus increasing the availability of loans). The availability of loans during low financial stress upon an expansionary monetary policy shock applies only in the longer term. A similar impact is observed on the demand side of the consumer loans market: Demand for loans instantly expands under an expansionary monetary policy shock during high financial stress, but only with a delay and by less in the low financial stress regime. The magnitude of the response is larger on the demand side of the market than on the supply side. 
Nonlinear Effects of Monetary Policy on the Consumer Loans Market

The second panel in Figure 2 traces the responses of credit standards and demand for loans during different GDP growth regimes of the euro area economy. In response to a stimulating monetary policy shock, banks lower credit standards, more during a low GDP growth regime than a normal GDP growth regime, while the increase in demand for loans is larger during a normal growth regime. Again, the response on the demand side of the market is larger than the response on the supply side.

The nonlinearities in the effect of monetary policy shocks on the consumer market variables may also stem from the size of shock because the nonlinear impulse responses may depend also on the size of the shock. To verify this, we computed nonlinear impulse responses to three STD shocks and scaled them by a factor of $1 / 3$ before drawing. Figure 3 presents the results of this exercise for an expansionary monetary policy shock in the two identified financial stress regimes, while Figure 4 shows the results for the GDP growth regimes. The results show that no nonlinearities are associated with the size of the shock. By and large, three times larger shocks result in three times larger credit standards and demand for loans responses.

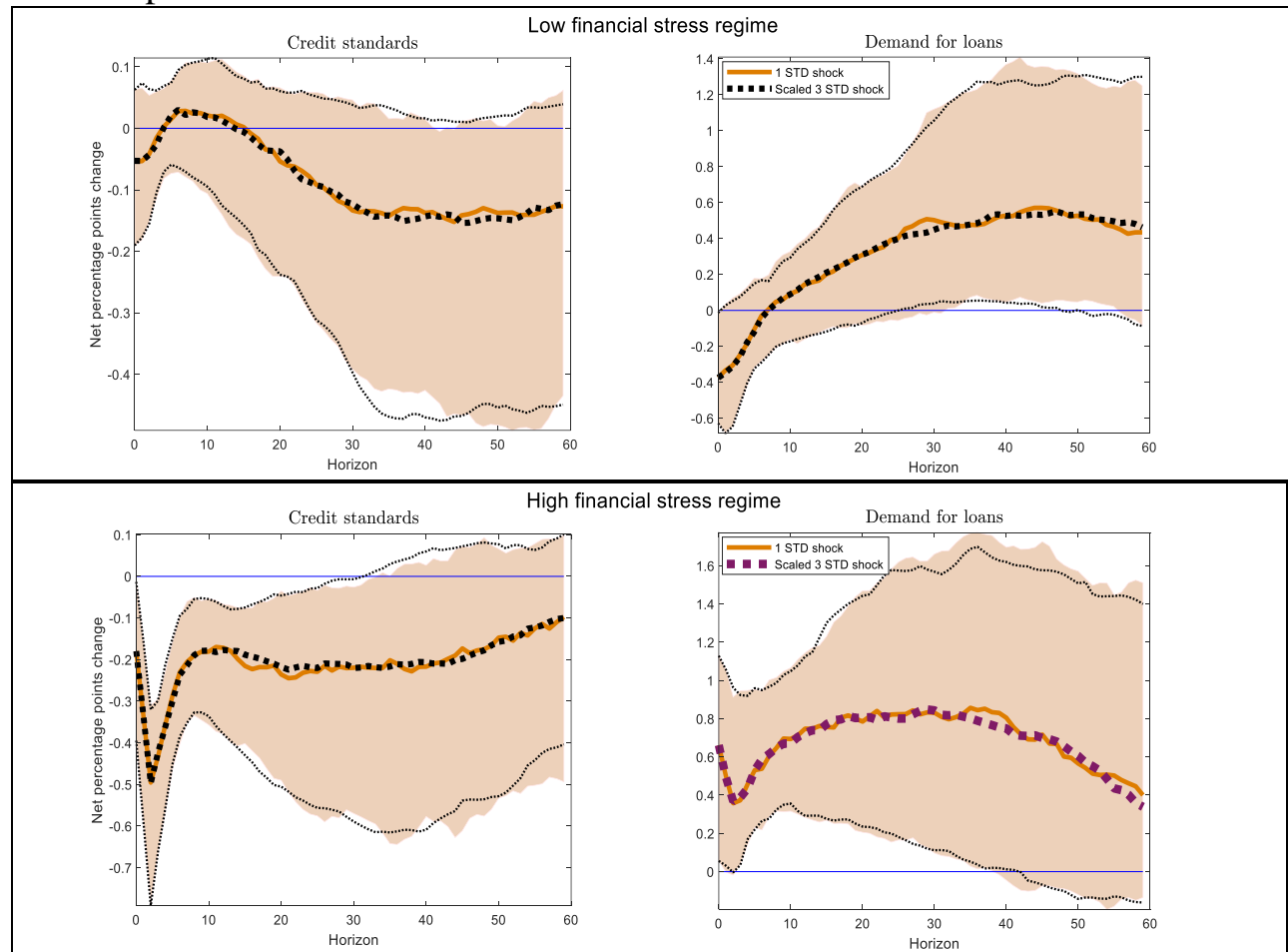

Note: Nonlinear median impulse responses of consumer loans market variables to 1 STD and to a scaled 3 STD (3 STD multiplied by 1/3) decrease in the ECB shadow rate $\left(i_{t}\right)$ over the horizon of five years and 68\% error bands.

Figure 3. Comparison of smaller and larger monetary policy shocks across different financial stress regimes

DOI: 10.24818/18423264/54.2.20.14 


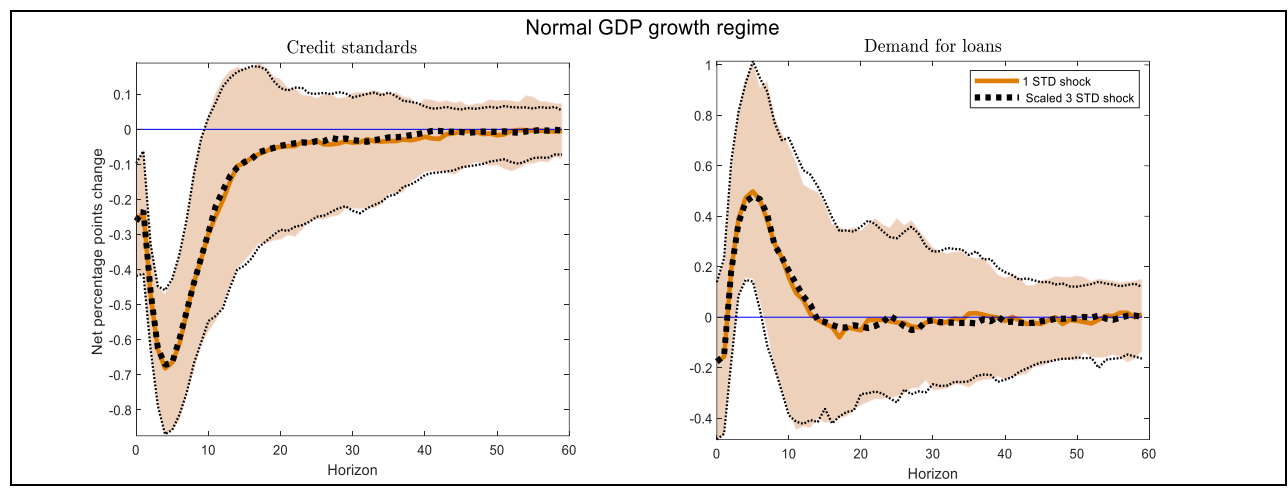

Notes: Nonlinear median impulse responses of consumer loans market variables to 1 STD and to a scaled 3 STD (3 STD multiplied by 1/3) decrease in the ECB shadow rate $\left(i_{t}\right)$ over the horizon of five years and 68\% error bands.

\section{Figure 4. Comparison of smaller and larger monetary policy shocks across different GDP growth regimes}

We tested the sensitivity of results to different orderings of variables for which there is not much guidance in the literature-credit market variables. In this, we placed $d_{t}$ before $s_{t}$, re-estimated the model, and computed nonlinear impulse responses; we found the results to be robust to this alternative recursive structure.

The results of the study imply that although the credit market exacerbates real and financial shocks (Brunnermeier\&Sanikov, 2011; Mittnik\&Semmler, 2013; Alessandri\&Mumtaz, 2017), due to financial accelerators(Bernanke \& Gertler, 1989; Bernanke et al., 1999), the sensitivity of a bank's balance sheet health to asset price volatility or interbank interdependencies (Brunnermeier\&Sanikov, 2011; Mittnik\&Semmler, 2013), and other potential propagators of real and financial shocks amplification, the monetary policy in the euro area was able to influence economic activity, financial stability, and credit activity in the observed period. Indeed, we found its efficiency elevated in the periods of increased financial stress and subdued economic activity when credit constraints are generally more binding. This does not suggest that monetary policy transmission in this period was not impaired. Several studies have documented that following the global financial crisis and the Great Recession important transmission channels were impaired (ECB, 2011; ECB, 2015). However, it does suggest that monetary policy measures undertaken, foremost unconventional policy, were successful in alleviating tensions in the financial system and stimulating the economy.

\section{Conclusions}

This paper utilized TVAR and nonlinear impulse analysis to separate two financial stress and two GDP growth regimes and then investigated the effects of monetary policy on credit standards (availability) and the demand for consumer loans during the period September 2004 - December 2018. The results show that 
Nonlinear Effects of Monetary Policy on the Consumer Loans Market

monetary policy is more efficient in stimulating consumer market activity and output during high financial stress and economic downturns than during "good times." In the consumer loans market, the response on the demand side is generally stronger than that on the supply side. We found no nonlinearities in the effect of monetary policy shocks on the consumer market variables associated with the size of the shock. The results do not imply that the monetary transmission was not affected during the recent financial and economic crises in the euro area but do suggest that unconventional measures undertaken enabled monetary policy to stimulate economic activity, alleviate financial stress, and improve conditions in the consumer loans market.

\section{REFERENCES}

[1] Afonso, A., Baxa, J. and Slavik, M. (2011),FiscalDevelopmentsandFinancialStress: A Threshold VAR Analysis. European Central Bank WorkingPaper No. 1319;

[2] Aikman, D., Lenhert A., Liang, N., Modugno, M.(2017), Credit, Financial Conditions, and Monetary Policy Transmission. Brookings Institution. Hutchins Center Working Paper No. 39;

[3] Alessandri, P. and Mumtaz, H. (2017), Financial Conditions and Density Forecasts for US Output and Inflation.Review of Economic Dynamics, 24, 66-78;

[4] Avdjiev, S., Zeng, Z. (2014), Credit Growth, Monetary Policy and Economic Activity in a Three-Regime TVAR Model.Applied Economics, 46(24), 2936-2951;

[5] Basu, S., Bundick, B. (2017), Uncertainty Shocks in a Model of Effective Demand. Econometrica, 85(3), 937-958;

[6] Baum, C., Caglayan, M., Ozkan, N. (2013), The role of uncertainty in the transmission of monetary policy effects on bank lending. The Manchester School, 81(2), 202-225;

[7] Bekaert, M., Hoerova, M., Duca, M.L. (2013), Risk, Uncertainty and Monetary Policy. Journal of Monetary Economics, 60(7), 771-788;

[8] Bernanke, B.S., Gertler, M. (1989), Agency Costs, Net Worth and Business Fluctuations.American Economic Review, Papers and Proceedings, 78(2), 435-439;

[9] Bernanke, B.S., Gertler, M., Gilchrist, S. (1999), The Financial Accelerator in a Quantitative Business Cycle Framework, in J.B. Taylor and $M$. Woodford (Eds., Handbook of Macroeconomics, Vol. 1 of Handbook of Macroeconomics, Elsevier, chapter 21, pp. 1341-1393.loom, N. 2009. The impact of uncertainty shocks. Econometrica, 77(3), 623-685;

[10] Bonciani, D., van Roye B. (2016), Uncertainty Shocks, Banking Frictions and Economic Activity. Journal of Economic Dynamics and Control, 73(C): 200-219;

DOI: 10.24818/18423264/54.2.20.14 
[11]Borio, C. (2014), The Financial Cycle and Macroeconomics: What Have We Learnt? Journal of Banking and Finance, 45, 182-198;

[12] Brady, R.R. (2008), Structural Breaks and Consumer Credit: Is Consumption Finally a Reality? Journal of Macroeconomics, 30(3), 12461268;

[13] Brunnermeier, M.K., Sannikov, Y. (2011), A Macroeconomic Model with Financial Sector.American Economic Review, 104(2), 379-421;

[14] Chang, J.-C., Jansen, W. D. (2005), The Effect of Monetary Policy on Bank Lending and Aggregate Output: Asymmetries from Nonlinearities in the Lending Channel. Annals of Economics and Finance, 6(1), 129-153;

[15] Chen, C. W., Lee, J. C. (1995), Bayesian Inference of Threshold Autoregressive Models.Journal of Time Series Analysis, 16(5), 483-492;

[16] Chow, G., Lin, A.L. (1971), Best Linear Unbiased Distribution and Extrapolation of Economic Time Series by Related Series.Review of Economics and Statistics, 53(4), 372-375;

[17] Dalhaus, T. (2017), Conventional Monetary Policy Transmission during Financial Crises: An Empirical Analysis.Journal of Applied Econometrics, 32(2), 401-421;

[18] ECB. (2011), The ECB's non-standard measures - impact and phasingout. ECB Monthly Bulletin, July 2011. ECB: Frankfurt;

[19] ECB. (2015), The transmission of the ECB's recent non-standard monetary policy measures. ECB Economic Bulletin, 7/2015. Frankfurt: European Central Bank;

[20] ECB. (2017),ECB Economic Bulletin, 7/2017. Frankfurt: European Central Bank;

[21] Gambacorta L., Rossi C. (2007), Modelling Bank Lending in the Euro Area: A Non-Llinear Approach. Banca d'Italia Working Papers No. 650;

[22] Holló, D., Kremer, M., Lo Duca, M. (2012), CISS - A Composite Indicator of Systemic Stress in the Financial System. European Central Bank Working Paper Series no. 1426;

[23] Jannsen N., Potjagailo G., Wolters M. H. (2015),Monetary Policy during Financial Crises: Is the Transmission Mechanism Impaired? Kiel Institute for the World Economy Working Paper No. 2005;

[24] Koop, G., Pesaran, M. H., Potter, S. M. (1996), Impulse Response Analysis In Nonlinear Multivariate Models.Journal of Econometrics, 74 (1), 119-147;

[25] Kremer, M. (2016), Macroeconomic Effects of Financial Stress and the Role of Monetary Policy: A VAR Analysis for the Euro Area. International Economics and Economic Policy, 13(1), 105-138;

[26] Lown, C.S., Morgan, D.P. (2006), The Credit Cycle and the Business Cycle: New Findings from the Loan Officer Opinion Survey. Journal of Money, Credit, and Banking, 38(6),1575-159;

[27]Miao, J. (2004), Consumption and Saving Under Knightian Uncertainty. Annals of Economics and Finance, 5(2), 299-311; 
Nonlinear Effects of Monetary Policy on the Consumer Loans Market

[28] Mittnik, S., Semmler, W. (2013), The Real Consequences of Financial Stress.Journal of Economic Dynamics \& Control, 37(8), 1479-1499;

[29] Mumtaz, H., Pirzada, A., Theodoridis, K. (2018), Non-Linear Effects of Oil Shock on Stock Prices. Working Papers 865, Queen Mary University of London, School of Economics and Finance;

[30] Quilis, M.E. (2019), Temporal Disaggregation. Matlab Code. MATLAB Central File Exchange. Available:

https://www.mathworks.com/matlabcentral/fileexchange/69800-temporaldisaggregation. Retrieved April 5, 2019;

[31] Tenreyro, S., Thwaites G. (2016), Pushing on a String: US Monetary Policy Is Less Powerful in Recessions. American Economic Journal: Macroeconomics, 8(4), 43-74;

[32] Wu, J.C., Xia, F.D. (2016), Measuring the Macroeconomic Impact of Monetary Policy at the Zero Lower Bound.Journal of Money, Credit, and Banking, 48(2-3), 253-291. 